\title{
INTERNATIONAL RELATIONS AS A FIELD OF STUDY IN THE CANADIAN SYSTEM OF HIGHER EDUCATION
}

\begin{abstract}
The research presents an attempt to investigate the current state of international relations as a field of study in the context of higher education system in Canada. It contains a general overview of the field of study, focusing predominantly on the role and function of the given academic discipline. The scientific investigation covers the issue of short historiographic review of the development of international relations as a separate academic discipline and an independent field of study at the universities of Canada since it provides better understanding of the international relations evolution as a discipline in Canadian system of higher education. It gives information on the origins of international relations discipline in Canada and first higher education establishments, which provided professional training in the international relations field. The article reviews the official normative documents in the sphere of higher education in Canada, such as Major Field of Study Classification and Classification of Instructional Programs, being theoretical basis of our analysis. The research results can be used to outline the place of international relations major among the diversity of functioning academic majors in Canada. The research also turns to the profound analysis of the information about the offered instructional programs, dedicated to professional training of international relations specialists at the universities of Canada.

Key words: field of study, academic major, discipline, professional training, instructional program, degree program, Bachelor's degree, Master's degree, Doctorate degree.

\section{INTRODUCTION}

International relations as a field of study play a significant role in the context of current global trends in the development of higher education systems. This is caused by the growing need for professional training of international relations specialists, as the construction of transnational cooperation, the analysis and solution of today's complex problems depend on their professionalism. Professional training of international relations specialists is traditionally implemented in the system of higher education. Well-developed training programs provide students with opportunities of successful formation and development of necessary knowledge and skills for future career. Higher education institutions in Canada offer effective training programs within international relations as a field of study and academic major, which, in its turn, is a prerequisite for the investigation of this positive experience to optimize the educational process in Ukraine.

THE AIM OF THE STUDY

The article presents a thorough study of international relations as a field of study in the contemporary higher education system in Canada. The author has defined the following objectives: 1) to conduct the analysis of scientific and pedagogical literature, which highlights different aspects of the problem under research; 2) to analyze the peculiarities of the formation, development and current role of international relations as a field of study in
\end{abstract}


Canadian system of higher education; 3) to explore the official classification of the fields of study and academic majors in Canada and define the role of international relations; 4) to investigate the Classification of Instructional Programs in Canada and find out, which of them are dedicated to the study of international relations.

In terms of the conducted research, it has been found that the formation of international relations as a separate field of study and a particular academic major is an important issue in modern pedagogical science. Nevertheless, the development of international relations as a field of study at Canadian universities still requires a profound study.

\section{THEORETICAL FRAMEWORK AND RESEARCH METHODS}

The theoretical and methodological fundamentals of our research are the following: the theses on modern philosophy of education (V. Andrushchenko, V. Kremen, I. Zyazyun); methodology of comparative education (N. Bidyuk, T. Desyatov, N. Lavrychenko, O. Lokshyna, N. Mukan, O. Ohiyenko, L. Pukhovska, A. Sbruyeva); continuous professional education (A. Kuzminskyy, N. Nychkalo); general structure of the organization and functioning of higher education in Canada (S. Honcharov, R. Hurevych, V. Karpinska, V. Moshynskyi); professional training of international relations specialists (N. Andrews, G. Hellman, S. Kormiltsyna, M. Morozov, M. Neufeld, B. Schmidt, S. Smith, O. Tarasova, V. Tretko); the content of professional education (N. Brukhanov, O. Kovalenko, M. Lazaryeva, N. Zhuravska).

During the last decades, comparative education and professional training of international relations specialists have been a matter of scientific and practical concern of foreign scientists (S. Ambrose, J. Bocock, P. Eckel, R. Gomes, S. Graham, S. Michael, J. Montgomery, J. Murry, G. Musambira, E. Neumann, M. Norman, J. Snyder) who have studied peculiarities of higher education and specificity of professional education in different countries.

In our research, the scientific papers of Ukrainian scholars (N. Avshenyuk, Ya. Belmaz, N. Bidyuk, Yu. Kishchenko, T. Koshmanova, M. Leshchenko, L. Pukhovska, A. Sbruyeva, S. Synenko, O. Zabolotna, I. Zadorozhna etc.) in comparative education are very important.

In our study we have used different theoretical and applied research methods. The comparative and historical methods have been used to study various aspects of the origin and development of international relations as a discipline, field of study, and distinct academic major. Logical method has been used for information processing, namely the study of available informational resources; induction and deduction - to formulate the statements and generalize the theoretical and matter-of-fact material; analysis and synthesis - to study theoretical materials, program documents of Canadian universities, norms, standards, and official documents, which regulate higher education in Canada. Among applied methods, we have used conversations and dialogues with the heads of departments at Canadian universities to gather primary pedagogical information.

\section{RESULTS}

International relations as a separate academic field of study emerged in the difficult period of the $\mathrm{XX}^{\text {th }}$ century and was established in terms of higher education system of the United Kingdom, namely at the University of Wales in 1919. Later on, London School of Economics and Political Science founded the Department of International Relations, offering students thorough professional training in compliance with the requirements of different degree programs. Having been successfully introduced to the British academic arena, international relations as a field of study started its rapid development in the United States of America and Switzerland. The important step on this path was made with the establishment of Graduate Institute of International and Development Studies in 1927 aimed predominantly at the study of international relations. Soon after that, intenational relations acquired considerable influence in the sphere of professional education. 
The establishment of American Academy of Political and Social Sciences also played an important role in shaping international relations into academic major and it gained vast scope of popularity in the USA. The state itself became dominant in research activity and professional training in international relations for the sake of national, political, and social goals. It was mostly interpreted as a subfield of political science. Due to numerous publications, international relations started to be characterized as an American social science (Smith, 2000).

Canada always shared the North American approach to the development of international relations, as well as its objectives to professional training of international relations specialists. Glendon College and Norman Paterson School of International Affairs were the first higher education establishments, which introduced Bachelor's and Master's degree programs in international relations. Moreover, Norman Paterson School of International Affairs is one of the current members of Association of Professional Schools of International Affairs. Nowadays, Canada has numerous successful degree programs in international relations, namely Bachelor's, Master's and Doctoral degrees.

As a result of successful development of international relations as the popularized field of study, the necessity appeared to set standards to regulate professional training in this sphere. The foundation of Association of Professional Schools of International Affairs in mid-1970s became an important achievement in the formation process of professional training in international relations. The association unites the higher education institutions, which offer degree programs in international relations. The main aim of the association is to promote the advancement of education quality and significance in the given sphere. The association counts more than 60 members from North America, Europe, and Asia. The membership in Association of Professional Schools of International Affairs presupposes that all the member institutions standardize and unify their degree programs to meet the mutual strategy in education (Association of Professional Schools of International Affairs, 2015).

Most countries with well-developed international relations establish correspondent professional and academic organizations. International Studies Association is considered to be very influential in the sphere. This association has been working both in North America and worldwide since 1959 to promote education and research in the sphere of international relations. Representatives of Canada are regular members of International Studies Association. Moreover, throughout its history, several prominent Canadian researchers chaired the association. On the regular basis, the association holds meetings and conferences in various Canadian cities such as Vancouver and Toronto (Gunther, 2011).

It is doubtless that Canada and its academic potential play one of the key roles in the activities of International Studies Association. One of the main objectives of Canada's international affairs, despite all the possible differences, is to provide support for the authorities in Ottawa in order to increase Canada's contribution protecting Pax Americana strategies (Healy, 2001).

Successful professional training contributes students' socialization in international relations institutions to enable them to become competent and responsible employees of the state apparatus. Canada has formed a favorable basis for professional development of future international relations specialists. Its system of higher education is considered to be effective due to its well-organized structure and positive learning outcomes. The normative documents such as Major Field of Study Classification and Classification of Instructional Programs, in its turn, help to regulate the educational process in the country.

Major Field of Study Classification was developed in 1986 to provide relevant data for Census of Population and other socio-economic researches. This document was later 
supplemented with Classification of Instructional Programs, which represents a list of degree programs and academic majors with the corresponding digital codes, which functions as the official standard in higher education system in Canada. Major Field of Study Classification is regularly reviewed and supplemented. The latest version is the officially documented classification that was used for 2001 Census of Population (Statistics Canada, 2001).

According to this classification, international relations as the field of study and academic major refer to Social Sciences and Related Fields, and to Political Science as a wider field of study. This field of study was given a digital code ' 165 '. In the context of this classification, international relations field has the following interpretation: "International relations is a branch of Political Science, which is oriented towards issues in the realm of international relations, including the origin of war, peace, diplomacy and economic relations between states.The study of international relations includes modern and historical aspects" (ibid).

The classification also provides the examples of the possible names of the degree programs, among which are International Affairs; International Policy; International Relations; International Studies etc.

Classification of Instructional Programs is a joint achievement of Statistics Canada and National Center for Education Statistics in the USA. This classification represents examples of different types of instructional programs, which are provided with the following definition: "The instructional program is a combination of the courses and practical experience, created to achieve certain goals or objectives such as preparation for further study, qualification for professional activities or enrichment of knowledge and understanding" (Statistics Canada, 2011).

Classification of Instructional Programs consists of three-stage hierarchical system. The first section presents the classification, in which educational programs are combined according to specific broad fields of study, which are marked with two-digit codes. These broad fields of study are divided into specific fields of study, which are marked with four-digit codes. These fields of study, in its turn, are divided into specific majors, according to which the separate instructional programs are classified. Every instructional program is marked with six-digit code. Thus, International Relations and National Security Studies as a field of study has a four-digit code ' 45.09 ', where the number ' 45 ' means belonging to a wider field of Social Sciences, and digits after the dot indicate the serial number in the classification (ibid).

This field of study includes the following instructional programs: 45.0901International Relations and Affairs, 45.0902 - National Security Policy Studies, 45.0999 International Relations and National Security Studies. Instructional programs within the same field of study are presented in the order, programs with more general focus of the study are located at the beginning (ibid).

The description of every instructional program including international relations contains a list of related programs that are to certain extent attributed to the same subject of study.

According to Classification of Instructional Programs, International Relations and Affairs (45.0901) is a type of instructional programs, which is focused on the systematic study of international politics and processes of international institutions in the field of diplomacy and foreign policy. These programs include the study of the courses on the theory of international relations, foreign policy analysis, national security, international law and organizations, comparative study of certain countries and regions, the theory and practice of diplomacy. Instructional programs within this field of study and specialization can have the following names: Foreign Policy and Diplomacy, International Affairs, International Politics, International Relations. The related programs in terms of the content 
of study are: Peace Studies and Conflict Resolution (30.0501), International Public Policy Analysis (44.0504), International / Global Studies (30.2001), National Security Policy Studies (45.0902), Political Science and Government, General (45.1001) (ibid).

It should be mentioned that the examples of related instructional programs help to identify the akin programs, which were included in other fields of study. The study of instructional programs offered by Canadian universities reveals that in addition to International Relations or International Affairs instructional programs, one can also find such similar programs as International / Global Studies (30.2001), which is dedicated to the study of related issues.

\section{CONCLUSIONS}

The results of our research have proven that Canada has a long and successful tradition of professional training in international relations according to the well-developed system of higher education, respective standards and requirements. Universities of Canada are highly rated among the known educational establishments, which offer programs in international relations. The positive reputation of Canadian professional training in international relations is achieved due to well-structured classification of fields of studies, which helps to determine the optimal objectives of specific instructional programs with orientation on balanced process of studying as well as on successful future professional activity.

Professional training of international relations specialists in Canada is a fruitful source for further research. In perspective, it represents profitable object for more detailed content analysis of professional training in the sphere of international relations within higher education in Canada. The future investigation will first and foremost elaborate on the issues, which are connected with such aspects as the Canadian assessment system of students' academic achievements and determination of learning outcomes. It is of importance to explore methods and classify the main forms and strategies, applied in professional training of international relations students.

\section{REFERENCES}

1. Healy, T. (2001). Critical Reflections on a Discipline: A Canadian Perspective. An Antipodean Electronic Journal of World Affairs, No. 3/97, p. 243-254.

2. Hellmann, G. (2011). International relations as a Field of Study. International Encyclopedia of Political Science, Volume 1, p. 1296-1314.

3. Official site of The Association of Professional Schools of International Affairs. (2015). Retrieved 20.02.2015 from : http://www.apsia.org.

4. Smith, S. (2000). The Discipline of International Relations: still an American Social Science? British Journal of Politics and International Relations, Volume 2, No. 3, p. 374-402.

5. Statistics Canada. (2011). Classification of Instructional Programs Canada, Catalogue No. 12-590-X, p. 693.

6. Statistics Canada. (2001). Major Field of Study. Retrieved 01.03.2015 from : http://www.statcan.gc.ca/subjects-sujets/standard-norme/mfs-pde/index-indexe-eng.htm. 